\title{
Arbitration
}

\section{The new Arbitration Act 1996}

$\mathrm{W}$

have a new Arbitration Act, that of 1996, which largely came into force on 31 January 1997 - save for the provisions dealing with 'domestic arbitration agreements' which for the time being do not apply. It applies to any arbitration proceedings starting on or after that date. The new Act, which repeals all prior statutes subject to transitional provisions (with the exception of Part 11 of the 1950 Act - 'enforcement of certain foreign awards'), has been masterminded by Lord Justice Saville and his committee. It has received a warm welcome. It follows in its own way the UN Committee on International Trade Law (UNCITRAL) Model Law, with clarity and simplicity and in logical order; and its interpretation is assisted by the Department Advisory Committee's reports, which have been produced to be read alongside the Act.

Three themes pervade the Act, spelt out in $\mathrm{s} .1$ :

(1) 'the object of arbitration is to obtain the fair resolution of disputes by an impartial tribunal without unnecessary delay or expense';

(2) 'the parties should be free to agree how their disputes are resolved, subject only to such safeguards as are necessary in the public interest';

(3) 'in matters governed by [the main part] of the Act the court should not intervene except as provided [in that part]'.

Of these themes, the first is given teeth by s. 33 of the Act. This is at the heart of the new legislation and is a directive to arbitration tribunals not only to be fair and impartial as between the parties, but also to adopt procedures that are expeditious and economical according to the case in hand.

\section{AUTONOMY}

In furtherance of the theme of party autonomy, most provisions of the Act apply only if the parties fail to agree otherwise (either directly or through any institutional rules adopted by them). Thus, the arbitrators are allowed to

\section{by Paul R Ellington}

parties have not decided otherwise, but are allowed, for example (and for the first time expressly), to exclude or limit discovery of documents and the rules of evidence - or to set their own - and the tribunal may take the initiative in ascertaining facts and law. Unless agreed otherwise the tribunal may award compound interest and freely fix the rate; but the tribunal cannot consolidate proceedings or order concurrent proceedings (especially useful to multipartite arbitration) unless the parties give it that power.

\section{COURT'S ROLE}

While the court necessarily retains some jurisdiction over arbitrations under the new Act, its role is narrower and more clearly and precisely defined. The grounds of appeal and resort to the court are more restricted than before in order to implement the parties' wishes to arbitrate their disputes. The court must order a stay of proceedings in favour of arbitration where an agrecment exists (as defined by the Act) unless it orders the agreement null and void, inoperative or incapable of performance. Where an arbitration agreement exists, the court now has no discretion as to whether or not it can take jurisdiction of a matter where it is submitted by a party that there is no dispute (such as, for example, in relation to an unpaid invoice, properly due): in such circumstances, whether or not a dispute properly exists, the matter must be referred to arbitration. Also, the general discretion, formerly available as to a domestic arbitration agreement (broadly one made in the UK between UK parties), disappears except where the agreement is void, etc., or (if and when the domestic arbitration provisions are brought into force) the court finds 'other sufficient grounds'.

In industries, such as construction, this has been much criticised since, prior to the new Act, there was a flexibility enabling the court to exercise its discretion to order a stay of numerous arbitrations between numerous parties all in relation to the same project or set of facts in favour of court proceedings; this enabled the parties to issue court proceedings in relation to such claims, thereby enabling joinder and/or consolidation. It seems such circumstances will not be 'other sufficient grounds' under the new Act to warrant a stay. Although the Act permits consolidation this can occur only by agreement of all the relevant parties; securing such agreement may not be possible. Accordingly, for all its enlightenment, there is a concern that industries formerly predisposed to arbitration will now be inclined to refer their disputes to the courts.

\section{INTERVENTION AND APPEAL}

The arbitration tribunal itself can determine its own substantive jurisdiction (unless otherwise agreed) but the parties' objections must be made promptly; and a party can take such an objection to a court, if all agree, or if the court allows it at its discretion and if the application is likely to cause a substantial saving of costs, is made without delay and the court considers there is 'good reason' for it to decide the issue. A party can also challenge in court a tribunal's award on its own jurisdiction but this right will be lost through delay or submission. The court can accept a challenge to an award on the ground of 'serious irregularity' (roughly what used to be called 'misconduct') but a party may lose this right to object also through delay or submission. A court can only (at its discretion) consider a preliminary point of law if the parties agree or if it is made promptly, with the consent of the tribunal and in a case where a substantial saving in costs is likely. Similarly an appeal on a point of law is allowed only if the parties have not excluded it (as by implication by dispensing with a reasoned award) and then only either by agreement of the parties or on grounds similar to those in Pioneer Shipping $v$ BTP Tioxide Ltd [1982] AC 724 (the 'Nema' case); the special rules restricting such exclusion that applied to shipping, insurance and commodity cases are abolished. 


\section{MARKET-LED}

A few general points: the parties can select the law applicable to the substance of the dispute or other considerations agreed by the parties (for example, ex aqueo et bono); unless otherwise agreed the award must state its reasons; the ability to correct or clarify the award is strengthened.

All in all, the Act is well prepared having been the subject of considerable consultation and being market-led to preserve and enhance the attractiveness of this jurisdiction. It provides a platform for arbitrators to differentiate arbitrations from court proceedings and gives the parties (subject to the Act's mandatory provisions) a wide element of choice to agree how their arbitrations are to be conducted.

It will be interesting to see how users cope with the extensive freedom now offered. Institutional bodies will amend (or have amended) their rules. Ad hoc appointers may not manage to take advantage of the possibilities till arbitration arises. Experience on these matters will provide a guide to later reforms. (1)

Paul R Ellington

Cameron McKenna

\section{International Trade}

\section{Slipping up on bananas?}

$\mathrm{T}$ he completion of the EU's internal market necessitated the unification of diverse national policies on banana imports into one policy; this came into force in July 1993. In the establishment of the trading system, among the various factors to be reconciled were the Lomé Convention's banana protocol, which provided for traditional Community imports from the $\mathrm{ACP}$ and the interests of Latin-American countries for whom banana exports were of major economic importance. In this reconciliation of interests, the need to make the regulation consistent with international trade law also had to be considered. The new regime was applauded by ACP producers as it allowed for the continuation of their traditional exports to the Community. However, Latin-American producers were very critical of the regime and a complaint was made to the GATT (General Agreement on Tariffs and Trade) yet the reports were not adopted. A further complaint was made by Ecuador, Guatemala, Honduras, Mexico and the US to the World Trade Organisation (WTO) in 1996.

\section{COMMUNITY IN BREACH}

In April 1997 the final report of the WTO panel concluded that the Community's import regime for bananas was inconsistent with various provisions of the GATT, the Licensing Agreement and the General Agreement on Trading Services (GATS). The Community's notification of an appeal against this report sought to challenge each of the specific findings against the Community's

\section{by Dr Joseph McMahon}

import regime and, more importantly, the interpretation of the scope and coverage of the waiver granted to the Lomé Convention and the obligations of the Community under that Convention. The Community argued that the waiver allowed for preferential treatment to be accorded to products, including bananas, originating in the ACP states, as required by the provisions of the Convention. The panel concluded that the Community had no obligation under the Convention to allocate tariff quota shares to the ACP in excess of their best-ever exports to the Community as they had under the banana regulation. By doing so, the Community had acted in breach of art. 13 and this breach was not covered by the waiver.

\section{FUTURE AMENDMENT}

The existing waiver expires in 2000 by which time the Convention will have been renegotiated. The Commission has offered a menu of six potential trade arrangements, none of which are problem-free. The ACP clearly would like the existing arrangements to continue. However, the Commission believes that some changes in those arrangements are necessary, not least to ensure their greater conformity with WTO rules. How is this difference to be resolved? Moreover could the relationship - and some ACP states survive the amendment of the banana regulation in line with the findings of the panel?

The most important factor in this resolution is the new atmosphere engendered by the WTO which makes it evident that the new Convention will be more consistent with those rules than previous Conventions. In terms of consistency, some adaptation of the existing agreement is necessary. The minimum requirement would be to introduce some element of reciprocity, but not all ACP countrics are in a position to offer reciprocal concessions. If reciprocity is offered and free tracle areas are contemplated, such areas must be consistent with art. 14. This too is problematic.

As for the more immediate problem facing the Community, the amendment of the banana regulation, one argument would be that if, after over 20 years of co-operation, ACP banana exports remain uncompetitive on the Community market, perhaps the time has come to end that co-operation. The economic cost to various ACP states of this option is too high to be realistically contemplated. If the appellate body confirms the panel report, the subsequent amendment of the banana regulation will need to consider this and the renegotiation of the current Lomé Convention will have to provide greater assistance to the affected ACP states. Otherwise, the Community will continue to slip up on bananas.

\section{Dr Joseph A McMahon \\ The Queen's University of Belfast}

